\title{
PLA2G7 Gene
}

National Cancer Institute

\section{Source}

National Cancer Institute. PLA2G7 Gene. NCI Thesaurus. Code C122064.

This gene is involved in platelet-activating factor modification. 